\title{
PENGEMBANGAN MODEL PEMBELAJARAN BUDI PEKERTI BERBASIS MULTIKULTURAL
}

\author{
Herimanto, Triyanto, Musa Pelu*
}

\begin{abstract}
Long-term goal of this study was to character-based learning model can be applied in the implementation of the multicultural character education curriculum in junior high school (SMP) in Surakarta as an effort to prevent a culture of violence in Surakarta. The target of this study is the identification of a model-based development of multicultural learning manners.

To achieve these objectives do Research and Development ( $R \& D$ ) gradually for 3 (three) years. This study used a qualitative paradigm, which I pursued in the exploratory method; year to second with the method of exposure, focus groups, workshops, and indepth interviews; year to III with training methods, test models, evaluation of the test results, the revised and improved model that has been tested, and dissemination of results. development. Concrete measures in the first year were identified: 1) initial ability of teachers to implement character education multicultural education based learning process in implementing character education curriculum. 2) Perception of teachers character education based on learning multicultural education. 3) Perceptions of stakeholders (Department Dikpora / Surakarta City Government, parents / guardians, school character education) to the learning process based multicultural education. 4) Identify the extent of the implementation of character education has been developed through a learning process based on multicultural education, and 5) draft a tentative model of the development of learning-based multicultural character as prevention of the culture of violence in Surakarta. Data collected from other informants, places and events as well as documents / files, or through focus groups, which further analyzed with interactive models.

The results obtained in the studies I dart this, namely: (1) The teachers have implemented a character education character-based multicultural learning through discussion methods, simulations, games, community service, observations, as well as the provision of materials in the classroom manners. However, most teachers do not understand the concept of multicultural education, (2) The teachers and stakeholders strongly support the learning plan based multicultural character, given that smells sara violence that often involve the students, (3) learning manners have been implemented with based multicultural through the process of learning, habituation, and modeling. Habituation and modeling performed by all the schools, while the learning process implemented by educators character education, (4) learning manners are still a lot of barriers or obstacles that come dart students, teachers / administrative staff-employees, the environment around the school, funds, facilities and infrastructure, principals, parents, and government policy.
\end{abstract}

Keywords: character, multicultural, violence

*Herimanto, Triyanto, Musa Pelu adalah Dosen Pendidikan Sejarah Universitas Sebelas Maret Surakarta 


\section{Pendahuluan}

Peristiwa kerusuhan yang terjadi pada tanggal 13-15 Mei 1998 adalah yang kesebelas kalinya menimpa Kota Surakarta. Dalam peristiwa itu terjadi aksi kerusuhan, penjarahan, pengrusakan, pembakaran rumah, toko, mobil perusahaan yang hampir seluruhnya milik warga etnik keturunan Cina. Selang satu tahun berikutnya yaitu pada bulan Nopember 1999 terjadi aksi kerusuhan yang diikuti dengan tindakan pembakaran terhadap gedung Balai Kota Surakarta serta pengrusakan sarana dan fasilitas umum lainnya.

Kedua peristiwa kerusuhan tersebut, mengindikasikan adanya tindakan kekerasan yang seolah-olah sudah menjadi perilaku umum atau budaya. Ironisnya, perilaku kekerasan tersebut banyak melibatkan para pemuda terutama pelajar.

Dilain pihak, aksi kekerasan tersebut memunculkan sebuah pertanyaan besar yaitu bagaimana mungkin kerusuhan bisa terjadi pada masyarakat yang memiliki kultur halus dengan nilai-nilai budaya Jawanya yang mementingkan prinsip kerukunan dan prinsip hormat melakukan tindakan yang sadis, amoral-asusila.

Visi Kota Surakarta sebagai kota budaya sekaligus kota pelajar hanya akan menjadi sebuah slogan tanpa makna, apabila tidak ada penanganan yang serius, terprogram dan menyeluruh untuk mengatasi aksi kekerasan tersebut. Untuk itu pemerintah Kota Surakarta bekerja sama dengan UNICEF melaksanakan suatu kebijakan berupa pelaksanaan "pendidikan budi pekerti" dalam kurikulum sekolah di SMP Kota Surakarta. Kebijakan ini merupakan salah satu langkah preventif untuk mengatasi budaya kekerasan di Kota Surakarta.

Kebijakan kurikulum pendidikan budi pekerti ini, pada dasarnya merupakan sebuah kebijakan pendidikan yang berbasis mulltikultural yang menghargai adanya perbedaan. Hal ini mengingat bahwa kerusuhan yang terjadi di Solo telah melibatkan rasa sentimen terhadap etnik tertentu yaitu etnik Cina.

Kerusuhan di Solo yang melibatkan sentimen terhadap etnik tertentu, mengajarkan kepada kita tentang pentingnya pendidikan multikultural yang menghargai adanya perbedaan. Oleh karena itu, perlu adanya pengembangan model pembelajaran berbasis pendidikan multikultural dalam pelaksanaan kurikulum pendidikan budi pekerti. 
Tinjauan Pustaka

\section{A. Pendidikan Budi Pekerti}

\section{Pengertian Pendidikan Budi Pekerti}

Pendidikan budi pekerti merupakan program pengajaran di sekolah yang bertujuan mengembangkan watak atau tabiat siswa dengan cara menghayati nilainilai dan keyakinan masyarakat sebagai kekuatan moral dalam hidupnya melalui kejujuran, dapat dipercaya, disiplin, dan kerja sama yang menekankan ranah afektif (perasaan dan sikap) tanpa meninggalkan ranah kognitif (berpikir rasional) dan ranah skill/psikomotorik (keterampilan, terampil mengolah data, mengemukakan pendapat, dan kerja sama).

Pengertian pendidikan budi pekerti menurut draft kurikulum berbasis kompetensi (2001) dapat ditinjau secara konseptual dan operasional. Secara konseptual pengertian pendidikan budi pekerti mencakup hal-hal sebagai berikut.

a) Usaha secara sadar untuk menyiapkan peserta didik menjadi manusia seutuhnya yang berbudi pekerti luhur dalam segenap peranannya sekarang dan masa yang akan datang. b) Upaya pembentukan, pengembangan, peningkatan, pemeliharaan dan per-baikan perilaku peserta didik agar mereka mau dan mampu melaksanakan tugas-tugas hidupnya secara selaras, serasi, seimbang (lahir batin, materiil spiritual dan individu sosial).

c) Upaya pendidikan untuk membentuk peserta didik menjadi pribadi seutuhnya yang berbudi pekerti luhur melalui kegiatan bimbingan, pembiasaan, pengajaran dan pelatihan serta keteladanan.

Adapun pengertian pendidikan budi pekerti secara operasional adalah upaya untuk membekali peserta didik melalui kegiatan, bimbingan, pengajaran dan latihan selama pertumbuhan dan perkembangan dirinya sebagai bekal bagi masa depannya,agar memiliki hati nurani yang bersih, berperangai baik serta menjaga kesusilaan dalam melaksanakan kewajiban terhadap Tuhan dan juga terhadap sesama makhluk, sehingga terbentuk pribadi seutuhnya yang tercermin pada perilaku berupa ucapan, perbuatan, sikap, pikiran, perasaan, kerja, dan hasil karya berdasarkan nilai-nilai agama serta norma dan moral luhur bangsa (Nurul Zuriah, 2007: 18-20). 


\section{Visi dan Misi Pendidikan Budi Pekerti}

Visi pendidikan budi pekerti diartikan sebagai kemampuan untuk memandang arah pendidikan budi pekerti ke depan dengan berpijak pada permasalahan saat ini untuk disusun perencanaan secara bijak. Menurut Cahyoto (2001) Visi pendidikan budi pekerti dalam lingkup PPKn ialah mewujudkan proses pengembangan budi pekerti siswa yang terarah kepada kemampuan berpikir rasional, memiliki kesadaran moral, berani mengambil keputusan dan bertanggung jawab atas perilakunya berdasarkan hak dan kewajiban warga negara yang pada gilirannya mampu bekerja sama dengan anggota masyarakat lainnya.

Menurut Buku I Pedoman Umum dan Nilai Budi Pekerti untuk Pendidikan Dasar dan Menengah (2000: 4), visi pendidikan budi pekerti adalah mewujudkan pendidikan budi pekerti sebagai bentuk pendidikan nilai, moral, etika yang berfungsi menumbuhkembangkan individu warga negara Indonesia yang berakhlak mulia dalam piker, sikap, dan perbuatannya sehari-hari, yang secara kurikuler benar-benar menjiwai dan memaknai semua mata pelajaran yang relevan serta sistem sosial-kultural dunia pendidikan sehingga dari dalam diri setiap lulusan setiap jenis, jalur, dan jenjang pendidikan terpancar akhlak mulia.

Adapun misi diartikan sebagai harapan pendidikan budi pekerti untuk mencapai tujuan pembelajaran. Berdasarkan pemahaman ini, maka menurut Cahyoto (2001) antara visi dan misi merupakan kesatuan yang berurutan langkahnya. Lebih lanjut misi pendidikan budi pekerti adalah sebagai berikut.

a) Membantu siswa memahami kecenderungan masyarakat yang terbuka dalam era globalisasi, tuntutan kualitas dalam segala bidang, dan kehidupan yang demokratis dengan tetap berlandaskan norma budi pekerti warga Negara Indonesia.

b) Membantu siswa memahami disiplin ilmu yang berperan mengembangkan budi pekerti sehingga diperoleh wawasan keilmuan yang berguna untuk mengembangkan penggunaan hak dan kewajibannya sebagai warga Negara.

c) Membantu siswa memahami arti demokrasi dengan cara belajar dalam suasana demokratis bagi upaya mewujudkan masyarakat yang lebih demokratis. 
Berdasarkan visi pendidikan budi pekerti menurut Buku I Pedoman Umum dan Nilai Budi Pekerti untuk Pendidikan Dasar dan Menengah (2000: 4) maka visi pendidikan budi pekerti adalah sebagai berikut.

a) Mengoptimalkan substansi dan praksis mata pelajaran yang relevan, khususnya Pendidikan Agama dan Pendidikan Pancasila dan Kewarganegaraan (PPKn), serta mata pelajaran lainnya yang relevan sebagai wahana pendidikan budi pekerti sehingga para peserta didik bukan hanya cerdas secara rasional, tetapi juga cerdas secara emosional, sosial, dan spiritual.

b) Mewujudkan tatanan dan iklim sosial budaya dunia pendidikan yang sengaja dikembangkan sebagai lingkungan pendidikan yang memancarkan akhlak/moral luhur sebagai wahana bagi siswa, tenaga kependidikan, dan manajer pendidikan untuk membangun interaksi edukatif dan budaya sekolah yang juga memancarkan akhlak mulia.

c) Memanfaatkan media massa dan lingkungan masyarakat secara selektif dan adaptif guna mendukung keseluruhan upaya penumbuhan dan pengembangan nilai-nilai budi pekerti luhur baik yang melalui mata pelajaran yang relevan maupun yang melalui pengembangan budaya pendidikan di sekolah (Nurul Zuriah, 2007: 6364).

\section{Tujuan Pendidikan Budi Pekerti}

Pendidikan budi pekerti secara umum bertujuan untuk memfasilitasi siswa agar mampu menggunakan pengetahuan, mengkaji dan menginternalisasi serta mempersonalisasi nilai, mengembangkan eterampilan sosial yang memungkinkan tumbuh dan berkembangnya akhlak mulia dalam diri peserta didik serta mewujudkan dalam perilaku sehari-hari dalam berbagai konteks sosial budaya yang berbhineka.

Sedangkan tujuan khusus pendidikan budi pekerti adalah sebagai berikut:

a) Mendorong kebiasaan dan perilaku peserta didik yang terpuji dan sejalan dengan nilainilai universal dan tradisi budaya bangsa yang religius.

b) Menanamkan jiwa kepemimpinan dan tanggung jawab peserta didik sebagai penerus bangsa. 
c) Memupuk ketegaran dan pekaan mental peserta didik terhadap situasi sekitarnya sehingga tidak ke dalam perilaku yang menyimpang baik secara individual maupun sosial.

d) Meningkatkan kemampuan untuk menghindari sifat-sifat tercela yang dapat merusak diri sendiri, orang lain dan lingkungan.

\section{Sasaran dan Ruang Lingkup}

\section{Materi Pendidikan Budi Pekerti}

$$
\text { Pendidikan budi pekerti }
$$

mempunyai sasaran kepribadian siswa, khususnya unsure karakter atau watak yang mengandung hati nurani (conscience) sebagai kesadaran diri (consciousness) untuk berbuat kebajikan (virtue).

Ruang lingkup materi pendidikan budi pekerti adalah pemahaman diri, gotong royong, kedisiplinan, rendah hati, tanggung jawab, pengendalian diri, pergaulan sehat, sopan santun, hormatmenghormati, kasih sayang, demokratis, adil dan bijaksana, taat pada ajaran agamanya dan toleransi antar umat beragama.

$$
\text { Menurut pendapat Cahyoto }
$$
(2002; 18-22), ruang lingkup atau scope pembahasan nilai budi pekerti yang bersumberkan pada etika atau filsafat moral menekankan unsur utama kepribadian, yaitu kesadaran dan berperannya hati nurani kebajikan bagi kehidupan yang baik berdasarkan sistem dan hukum nilai-nilai moral masyarakat. Hati nurani (kata hati, suara hati, dan suara batin) adalah kesadaran untuk mengendalikan atau mengarahkan perilaku seseorang dalam hal-hal yang baik dan menghindari tindakan yang buruk. Kebajikan atau kebaikan merupakan watak unggulan yang berguna dan menyenangkan bagi diri sendiri dan orang lain sesuai dengan pesan moral (Solomon, 1984; 100).

Dengan demikian, terdapat hubungan antara budi pekerti dengan nilai-nilai moral dan norma hidup yang unsur-unsurnya merupakan ruang lingkup pembahasan budi pekerti. Unsur-unsur budi pekerti antara lain, hati nurani, kebajikan, kejujuran, dapat dipercaya, disiplin, kesopanan, kerapian, keikhlasan, kebijakan, pengendalian diri, keberanian, bersahabat, kesetiaan, kehormatan, dan keadilan.

\section{B. Konsep Pendidikan Multikultural}

1. Pengertian Pendidikan Multikultural Menurut Andersen dan Cusher (Choirul Mahfud, 2006 : 167), pendidikan multikultural diartikan 
sebagai pendidikan mengenai keragaman kebudayaan. Sedangkan James Banks (Choirul Mahfud, 2006: 168), mendefinisikan pendidikan multikultural sebagai pendidikan untuk people of color. Artinya, pendidikan multikultural ingin mengeksplorasi perbedaan sebagai keniscayaan (anugerah Tuhan/sunatullah). Kemudian, bagaimana kita mampu mensikapi perbedaan tersebut dengan penuh toleran dan semangat egaliter.

Sejalan dengan pemikiran diatas, Muhaemin el Mahady berpendapat bahwa pendidikan multikultural merupakan pendidikan tentang keragaman kebudayaan dalam merespon perubahan demografis dan kultural lingkungan masyarakat tertentu atau bahkan dunia secara keseluruhan (global) (Choirul Mahfud, 2006: 168).

Dalam bukunya Multicultural Education : A Teacher Guide to Linking Context, Process, and Content, Hilda Hernandez mengartikan pendidikan multikultural sebagai perspektif yang mengakui realitas politik, sosial, dan ekonomi yang dialami oleh masingmasing individu dalam pertemuan manusia yang kompleks dan beragam secara kultur, dan merefleksikan pentingnya budaya, ras, seksualitas dan gender, etnisitas, agama, status sosial, ekonomi, dan pengecualianpengecualian dalam proses pendidikan.

Sonia Nieto dalam tulisannya Multicultural Education: Multicultural Schools(2000:300) menyatakan bahwa "Multicultural Education is a process rategies used in schoof comprehensive school reform and basic education for all students. It challenges and rejects racism and other forms of discrimination in schools and society and accepts and affirms the pluralism (ethnic, racial, linguistic, religious, economic, and gender, among others) that students, their communities, and teachers represent. Multicultural education permeates the curriculum and instructional stols, as well as the interactions among teachers, students, and parents, and the very way that schools conceptualize the nature of teaching and learning".

Menurut Syahiq A Mughni (Choirul Mhfud, 2006 : viii), pendidikan multikultural dirumuskan sebagi wujud kesadaran tentang keanekaragaman kultural, hak-hak asasi manusia serta pengurangan atau penghapusan berbagai berbagai jenis prasangka atau prejudise untuk membangun suatu kehidupan masyarakat yang adil dan maju. Pendidikan multikultural juga dapat diartikan sebagai strategi untuk mengembangkan kesadaran atas 
kebanggaan seseorang terhadap bangsanya (the pride in one's home nation).

Selanjutnya, James Banks menjelaskan bahwa pendidikan multikultural memiliki beberapa dimensi yang saling berkaitan satu dengan yang lain, yaitu: Pertama, Content Integration, yaitu mengintegrasikan berbagai budaya dan kelompok untuk mengilustrasikan konsep mendasar, generalisasi dan teori dalam mata pelajaran / disiplin ilmu. Kedua, The Knowledge Construction Proces, yaitu membawa siswa untuk memahami implikasi budaya kedalam sebuah mata pelajaran (disiplin).

Ketiga, An Equity Paedagogy, yaitu menyesuaikan metode pengajaran dengan cara belajar siswa dalam rangka memfasilitasi prestasi akademik siswa yang beragam baik dari segi ras, budaya (Culture) ataupun sosial (Social). Keempat, Prejudice Reduction, yaitu mengidentifikasi karakteristik ras siswa dan menentukan metode pengajaran mereka. Kemudian, melatih kelompok untuk berpartisipasi dalam kegiatan olahraga, berinteraksi dengan seluruh staff dan siswa yang berbeda etnis dan ras dalam upaya menciptakan budaya akademik yang toleran dan inklusif (James A. Banks,2000:220-22).
Menurut Prof. HAR Tilaar, pendidikan multikultural sebenarnya merupakan sikap "peduli" dan mau mengerti (difference), atau politics of recognition (politik pengakuan terhadap orang-orang dari kelompok minoritas) (Jurnal PKn Progresif, Muh. Hendri Nuryadi, 2006 : 304).

Sedangkan Ali Maksum mengemukakan 4 (empat) ciri pendidikan multikultural, yaitu 1) tujuannya membentuk "manusia budaya" dan menciptakan "masyarakat berbudaya (berperadaban)” , 2) materinya mengajarkan nilai-nilai luhur kemanusiaan, nilai-nilai bangsa dan nilai-nilai kelompok etnis (kultural), 3) metodenya demokratis, yang menghargai aspek-aspek perbedaan dan keberagaman budaya bangsa dan kelompok etnis (kultural), dan 4) evaluasinya ditentukan pada penilaian terhadap tingkah laku anak didik yang meliputi persepsi, apresiasi, dan tindakan terhadap budaya lainnya. (Jurnal PKn Progresif, Muh. Hendri Nuryadi, 2006 : 305).

2. Urgensi Pendidikan Multikultural di Indonesia

Menurut Choirul Mahfud (Jurnal PKn Progresif, Harmanto, 2006 : 296), ada tiga urgensi pendidikan multikultural di Indonesia. Pertama, pendidika multikultural berfungsi 
sebagai sarana alternatif pemecahan masalah. Penyelenggaraan pendidikan multikultural di dunia pendidikan diyakini dapat menjadi solusi nyata bagi konflik dan disharmonisasi yang terjadi di masyarakat, khususnya yang kerap terjadi di masyarakat Indonesia yang secara realistis plural. Dengan lain kata, pendidikan multikultural dapat menjadi sarana alternatif pemecahan konflik sosial-budaya.

Spektrum kultur masyarakat Indonesia yang amat beragam menjadi tantangan bagi dunia pendidikan guna mengolah perbedaan tersebut menjadi suatu aset, bukan sumber perpecahan. Saat ini, pendidikan multikultural mempunyai dua tanggung jawab besar, yaitu menyiapkan bangsa Indonesia untuk siap menghadapi arus budaya luar di era globalisasi dan menyatukan bangsa sendiri yang terdiri dari berbagai macam budaya.

Sekolah maupun perguruan tinggi sebagai institusi pendidikan dapat mengembangkan pendidikan multikultural dengan model masingmasing sesuai asas otonomi pendidikan atau sekolah. Pendidikan multikultural sebaiknya lebih ditekankan pada mata pelajaran kebangsaan dan moral.

Pada dasarnya, model-model pembelajaran sebelumnya yang berkaitan dengan kebangsaan memang sudah ada. Namun, hal itu masih kurang memadai sebagi sarana pendidikan guna menghargai perbedaan suku, budaya, etnis. Hal itu menunjukkan toleransi masih amat kurang.

Kedua, Supaya siswa tidak tercerabut dari akar budaya. Pendidikan multikultural juga signifikan dalam membina siswa agar tidak tercerabut dari akar budaya yang ia miliki sebelumnya, tatkala berhadapan dengan realitas sosial-budaya di era globalisasi.

Di era globalisasi saat ini, pertemuan antar budaya menjadi ancaman seruis bagi anak didik. Untuk mensikapi realitas global tersebut, siswa hendaknya diberi penyadaran akan pengetahuan yang beragam, sehingga mereka memiliki kompetensi yang luas akan pengetahuan global termasuk aspek kebudayaan. Mengingat beragamnya relitas kebudayaan di Indonesia maupun di luar negeri, siswa pada era globalisasi perlu diberi materi tentang pemahaman banyak budaya, atau pendidikan multikultural, agar siswa tidak tercerabut dari akar budayanya.

Ketiga, sebagai landasan pengembangan kurikulum nasional. Dalam melakukan pengembangan kurikulum sebagai titik tolak dalam proses belajar mengajar, atau guna memberikan sejumlah materi dan isi 
pelajaran yang harus dikuasai oleh siswa dengan ukuran atau tingkat tertentu, pendidikan multikultural sebagai landasan pengembangan kurikulum menjadi sangat penting.

Pengembangan kurilkulum masa depan yang berdasarkan pendekatan multikultural dapat dilakukan berdasarkan langkah-langkah sebagai berikut: (1) Mengubah filosofi kurikulum dari yang berlaku seragamseragam seperti saat ini kepada filosofi yang lebih sesuai dengan tujuan, misi dan fungsisetiap jenjang pendidikan dan unit pendidikan, (2) Teori kurikulum tentang konten (curriculum content) haruslah berubah dari teori yang mengartikan konten sebagai aspek substantif yang berisikan fakta, teori, generalisasi ke pengertian yang mencakup pula nilai moral, prosedur, proses dan keterampilan (skills) yang harus dimiliki generasi muda,

(3) Teori belajar yang digunakan dalam kurikulum masa depan yang memperhatikan keragaman sosial, budaya, ekonomi, dan politik tidak boleh lagi hanya mendasarkan diri pada teori psikologi belajar yang menempatkan siswa sebagai makhluk sosial, budaya, politik, yang hidup sebagai anggota aktif masyarakat, bangsa , dan dunia yang harus diseragamkan oleh institusi pendidikan,
(4) Proses belajar yang dikembangkan untuk siswa haruslah berdasarkan proses yang memiliki tingkat isomorphisme yang tinggi dengan kenyataan sosial. Artinya, proses belajar yang mengandalkan siswa belajar secara individualistis harus ditinggalkan dan diganti dengan cara belajar berkelompok dan bersaing secara kelompok dalam suatu situasi posistif, dan (5) Evaluasi yang digunakan haruslah meliputi keseluruhan aspek kemampuan dan kepribadian peserta didik, sesuai dengan tujuan dan konten yang dikembangkan (Choirul Mahfud, 2006 : 207 - 216).

3. Pemberlakuan Pendidikan Multikultural

Pertentangan etnis yang terjadi di Indonesia beberapa tahun terakhir, mengajarkan betapa pentingnya pendidikan multikultural bagi masyarakat. Meskipun secara formal bangsa Indonesia mengakui keragaman, namun dalam kenyataannya tidak.

Pada masa orde baru, pendidikan merupakan bagian dari indoktrinasi politik untuk mendukung rezim yang sedang berkuasa. Hampir tidak ada ruang untuk mengungkapkan identitas lokal dalam sistem pendidikan. Yang ada hanyalah kebudayaan nasional. Padahal lokalisme dalam pendidikan multikultural merupakan 
bagian yang paling penting. Disitulah orang dapat melihat dirinya (self). Disitu pula orang bisa melihat keragaman orang lain (other).

Pada prinsipnya, pendidikan multikultural adalah pendidikan yang menghargai perbedaan. Pendidikan multikultural senantiasa menciptakan struktur dan proses dimana setiap kebudayaan bisa melakukan ekspresi. Ada dua hal yang harus diperhatikan untuk mewujudkan pendidikan multikultural yang mampu memberikan ruang kebebasan bagi semua kebudayaan untuk berekspresi. Pertama, adalah dialog. Pendidikan multikultural tidak mungkin berlangsung tanpa dialog. Dalam pendidikan multikultural, setiap peradaban dan kebudayaan yang ada berada dalam posisi yang sejajar dan sama. Tidak ada kebudayaan yang lebih tinggi atau dianggap lebih tinggi (superior) dari kebudayaan lain. Dialog meniscayakan adanya persamaan dan kesamaan di antara pihak-pihak yang terlibat. Dengan dialog, diharapkan terjadi sumbang pemikiran yang pada gilirannya akan memperkaya kebudayaan atau peradaban yang bersangkutan.

Disamping sebagai pengkayaan, dialog juga sangat penting untuk mencari titik temu (kalimatun sawa) antar peradaban dan kebudayaan yang ada. Dialog diharapkan dapat mencari titik-titik persamaan sambil memahami titik-titik perbedaan antar kebudayaan.

Kedua, adalah toleransi. Toleransi adalah sikap menerima bahwa orang lain berbeda dengan kita. Dialog dan toleransi merupakan satu kesatuan yang tidak dapat dipisahkan. Bila dialog itu bentuknya, toleransi itu isinya. Toleransi diperlukan tidak hanya pada tataran konseptual, melainkan juga pada tingkat teknis operasional. Inilah yang sejak lama absen dalam sistem pendidikan kita (Jurnal PKn Progresif, Rima, 2006 : 255 - 256).

\section{Budaya Kekerasan}

Menurut sejarawan Djoko Suryo, gejala kekerasan pada hakekatnya merupakan bagian yang tidak terpisahkan dari kehidupan manusia, setua sejarah manusia sendiri. Dari perspektif kebudayaan Islam, gejala kekerasan dipandang sebagai salah satu ciri dari kehidupan manusia yang belum beradab atau yang masih hidup pada tingkat barbar atau jahiliyah (kegelapan). Ironisnya, meskipun umat manusia telah mencapai tingkat kebudayaan dan peradaban yang tinggi, modern tetapi realitas menunjukkan bahwa umat manusia tetap harus bergumul dengan gejala kekerasan yang semakin tinggi kualitasnya dan 
kuantitasnya. Gejala kekerasan ini menjadi ancaman utama bagi perdamaian kehidupan manusia.

Merupakan kenyataan bahwa kekerasan telah menjadi semacam "budaya" di tengah-tengah kehidupan masyarakat kita. Setiap gesekan, pertentangan, dan konflik sering berakhir dengan tindakan penganiayaan, perkelahian massal, aksiaksi pembakaran terhadap fasilitasfasilitas umum, kerusuhan, dan pembunuhan. Intinya masyarakat begitu mudah untuk diprovokasi.

Gesekan kecil saja dengan mudah memicu tindakan kekerasan dan dengan cepat melibatkan komunitaskomunitas yang bersangkutan secara kolektif. Apabila di suatu daerah, kampung atau desa, terdapat dua komunitas/penduduk yang saling berbeda suku, etnis, agama, atau antara penduduk asli dengan penduduk pendatang, maka kemungkinan terjadi perang dan bentrok antar suku, agama, dan antara penduduk asli dan pendatang sangat mungkin terjadi. Misalnya, kerusuhan Mei 1998 di Kota Surakarta dan Jakarta, konflik Ambon yang bernuansa perang agama, konflik di Kalimantan Barat yang merupakan konflik antar etnis. Di Jakarta, ada bentrokan antar warga kampung yang saling bertetangga (Musa Pelu, 2001).
Selain itu, dalam setiap pertandingan sepak bola sering berakhir dengan bentrokan, baik antar pemain, pemain dengan supporter maupun antar supporter.Akhir-akhir ini, tindakan kekerasan yang sering terjadi adalah "pengadilan massa" terhadap pencuri. Massa rakyat yang kebetulan memergoki atau menangkapnya maka secara spontan beramai-ramai menghajar pencuri itu, bahkan tidak jarang kemudian membakarnya.

Menurut Frans Magnis Suseno, apabila dalam suatu masyarakat intensitas kekerasan bertambah, berarti masyarakat itu sedang sakit. Kondisi inilah yang sekarang dialami masyarakat Indonesia. Proses penyembuhannya harus dicari pada sumber atau latar belakang munculnya kekerasan tersebut, baru kemudian dilakukan penyembuhannya dengan memberi formulasi obat yang tepat untuk menciptakan kembali masyarakat yang sehat yang jauh dari tindakan kekerasan (Yayah Khisbiyah dkk., 2000: viii).

\section{Metode Penelitian}

Penelitian ini bersifat research and development yang dilakukan secara bertahap dalam waktu 3 (tiga) tahun. Tahap pertama dilakukan pada tahun 2012, tahap kedua dilakukan pada tahun 2013, dan tahap ketiga pada 
tahun 2014. Pada tahun pertama penelitian dilakukan untuk : 1) Mengidentifikasi kemampuan awal guru-guru pendidikan budi pekerti untuk melaksanakan proses pembelajaran berbasis pendidikan mutikultural dalam pelaksanaan kurikulum pendidikan budi pekerti, 2) Mengidentifikasi persepsi para guru dan stakeholders pendidikan budi pekerti terhadap proses pembelajaran berbasis pendidikan mutikultural, mengidentifikasi sejauhmana pelaksanaan pendidikan budi pekerti telah dikembangkan melalui proses pembelajaran berbasis pendidikan mutikultural, serta menemukan model pengembangan pembelajaran berbasis pendidikan multikultural secara tentatif. Untuk mencapai tujuan tersebut digunakan metode eksploratif, yang dilakukan secara langsung di lapangan.

$$
\text { Untuk menghimpun data }
$$

diperoleh dari: (1) sumber informan, (2) sumber tempat dan peristiwa, serta (3) sumber dokumentasi/arsip yang ada..Untuk menggali data dari berbagai sumber tersebut dilakukan dengan (1) wawancara mendalam, (2) pengamatan langsung dan (3) analisis isi data-data dokumen/arsip.

Untuk meningkatkan tingkat ketidakpercayaan data dilakukan dengan beberapa teknik, antara lain: peerdebriefing, yaitu diskusi dengan beberapa personal (guru yang terlibat dalam pembelajaran budi pekerti, pakar pendidikan, budayawan, kepala sekolah, Dinas Pendidikan dan Kebudayaan) yang setara pengetahuannya dengan tim peneliti (Penulis). Hal ini dimaksudkan untuk mempertajam, untuk koreksi maupun untuk memperoleh masukanmasukan serta kritikan-kritikan, sehingga data hasil informasi benarbenar telah teruji kebenarannya. Teknik trianggulasi sumber juga dilakukan sebagai cara mempertinggi kebenaran data, yakni dengan mengecek data dari beberapa sumber yang berbeda mengenai masalah yang sama. Sedangkan langkah untuk mendapatkan kebenaran informasi setiap informan, dilakukan dengan teknik recheck, yaitu upaya meneliti data hasil wawancara dari informan untuk memperoleh tingkat kebenaran data dari informan yang telah dimintai informasi.

$$
\text { Pengelolaan data hasil }
$$

penelitian dilakukan dengan teknik analisis model interaktif (Miles dan Huberman, 1984), yang meliputi komponen: 1) pengumpulan data, 2) reduksi data, 3) sajian data dan 4) penarikan kesimpulan (verifikasi). Berikut ini bagan analisis siklus proses analisis interaktif. 


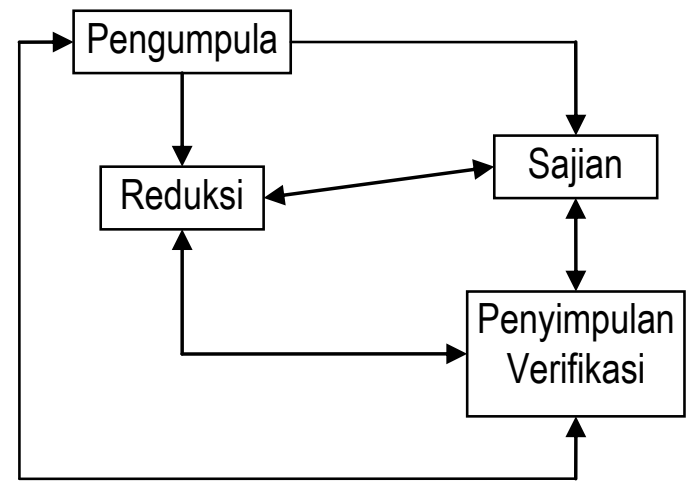

Bagan 1: Model Analisis Interaktif Sumber: Miles \& Huberman (1984)

\section{Hasil Penelitian dan Pembahasan}

\section{A. Hasil Penelitian}

\section{Kemampuan Awal Guru-Guru Pendidikan Budi Pekerti}

Para guru pendidikan budi pekerti telah menerapkan pembelajaran budi pekerti berbasis multikultural melalui metode diskusi, simulasi, permainan, kerja bakti, observasi, maupun pemberian materi budi pekertif di kelas. Namun demikian, sebagian besar guru belum memahami konsep pendidikan multikultural. Para guru sadar maupun tidak, pada intinya telah melaksanakan pembelajaran budi pekerti berbasis multikultural, tetapi tidak didasari pemahaman tentang bagaimana seharusnya pendidikan multikultural itu diimplementasikan dalam proses pembelajaran budi pekerti. Dampaknya, konsep pendidikan budi pekerti yang latar belakangnya ditujukan untuk mengatasi budaya kekerasan sebagai akibat kurangnya pemahaman tentang esensi perbedaan atau multikultural dalam masyarakat, khususnya dikalangan pelajar, tidak dapat dilaksanakan secara optimal.

Pemahaman tentang konsep pendidikan multikultural dikalangan guru dapat dibagi menjadi tiga tingkatan, yaitu: 1). Para Guru yang belum sama sekali mengetahui tentang konsep pendidikan multikultural, bahkan bisa dikatakan bahwa mereka baru mendengar tentang konsep pendidikan multikultural, 2). Para guru yang kurang memahami tentang konsep pendidikan multikultural, tetapi mereka mengetahui konsep pendidikan multikultural dari berbagai kegiatan organisasi, forum ilmiah yang pernah mereka ikuti. Kekurangpahaman mereka ini disebabkan karena dari forom-forum yang pernah mereka ikuti itu tidak secara spesifik membahas tentang pendidikan multikultural. Jadi bukan menjadi tema utamanya, 3) Ada sebagian kecil atau beberapa guru yang sudah cukup paham tentang konsep pendidikan multikultural. Pemahaman ini mereka dapatkan dari buku-buku yang mereka baca terkait pendidikan multikultural dan forum-forum ilmiah yang mereka ikuti. Bahkan mereka ini telah menerapkan konsep-konsep dalam pendidikan multikultural ini 
dalam pembelajaran pendidikan budi pekerti yang mereka ampu. Penerapannya melalui berbagai metode pembelajaran yang bervariasi, seperti metode diskusi, simulasi, permainan, wawancara, kerja bakti, observasi, pembiasaan, dan keteladanan. Dapat disimpulkan bahwa mereka dapat secara optimal dalam melaksanakan proses pembelajaran budi pekerti berbasis multikultural. Dampaknya terhadap budi pekerti siswa juga cukup signifikan. Baik itu terkait dengan sikap, perilaku, dan bicara siswa.

\section{Persepsi Guru dan Stokeholders Terhadap Pembelajaran Berbasis Multikultural}

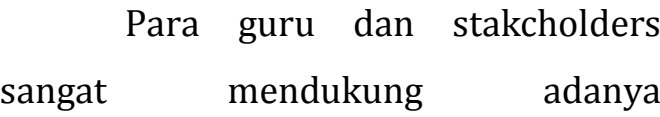
pembelajaran budi pekerti berbasis multikultural, mengingat kasus kekerasan yang berbau sara yang sering melibatkan para pelajar. Menurut mereka, harus ada suatu metode atau model pembelajaran budi pekerti yang tepat agar tujuan awal dari diperlakukannya pendidikan budi pekerti tersebut dapat tercapai. Mereka juga prihatin terhadap perilaku para pelajar sekarang yang masih jauh dari nilai-nilai moral, seperti perkelahian antar pelajar atau geng-geng pelajar, penggunaan narkoba, lunturnya nilainilai budaya Jawa dikalangan pelajar, perilaku membolos, tindakan kriminal, dan yang lebih memprihatinkan lagi yaitu terlibatnya para pelajar dalam kerusuhan Mei 1998 di Kota Surakarta.

Dalam peristiwa kerusuhan itu terjadi aksi kerusuhan, penjarahan, pengrusakan, pembakaran rumah, toko, mobil perusahaan yang hampir seluruhnya milik warga etnik keturunan Cina. Selang satu tahun berikutnya yaitu pada bulan Nopember 1999 terjadi aksi kerusuhan yang diikuti dengan tindakan pembakaran terhadap gedung Balai Kota Surakarta serta pengrusakan sarana dan fasilitas umum lainnya. Ironisnya, perilaku kekerasan tersebut banyak melibatkan para pemuda terutama pelajar.

Dilain pihak, aksi kekerasan tersebut memunculkan sebuah pertanyaan besar yaitu bagaimana mungkin kerusuhan bisa terjadi pada masyarakat yang memiliki kultur halus dengan nilai-nilai budaya Jawanya yang mementingkan prinsip kerukunan dan prinsip hormat melakukan tindakan yang sadis, amoral-asusila.

Visi Kota Surakarta sebagai kota budaya sekaligus kota pelajar hanya akan menjadi sebuah slogan tanpa makna, apabila tidak ada penanganan yang serius, terprogram dan menyeluruh untuk mengatasi aksi kekerasan tersebut. Untuk itu 
pemerintah Kota Surakarta bekerja sama dengan UNICEF melaksanakan suatu kebijakan berupa pelaksanaan "pendidikan budi pekerti" dalam kurikulum sekolah di SMP Kota Surakarta. Kebijakan ini merupakan salah satu langkah preventif untuk mengatasi budaya kekerasan di Kota Surakarta.

Kebijakan kurikulum pendidikan budi pekerti ini, pada dasarnya merupakan sebuah kebijakan pendidikan yang berbasis mulltikultural yang menghargai adanya perbedaan. Hal ini mengingat bahwa kerusuhan yang terjadi di Solo telah melibatkan rasa sentiment terhadap etnik tertentu yaitu etnik Cina. Oleh karena itu, para guru dan stakeholders menilai bahwa rencana implementasi proses pembelajaran budi pekerti berbasis multikultural sangatlah sesuai dan tepat untuk mengatasi budaya kekerasan di Kota Surakarta ini.

\section{Proses Pembelajaran Pendidikan Budi Pekerti Berbasis Multikultural}

\section{a. Implementasi Pendidikan Budi}

\section{Pekerti di Kelas}

Implementasi

proses

pembelajaran budi pekerti berbasis multikultural pada umumnya lebih merupakan penerapan dari nilai-nilai budaya Jawa yang dianggap sangat relevan dengan konsep pendidikan multikultural yang lebih mengedepankan nilai-nilai toleransi, saling menghargai dan menghormati adanya perbedaan.

Ada dua kaidah dasar dalam kehidupan masyarakat Jawa, yaitu "prinsip kerukunan dan prinsip hormat". Kedua prinsip tersebut merupakan kerangka normatif yang menentukan bentuk-bentuk konkret semua interaksi. Prinsip rukun bertujuan mempertahankan masyarakat dalam keadaan yang harmonis, yaitu dalam keadaan selaras, tenang dan tenteram, tanpa perselisihan atau pertentangan. Prinsip hormat mempunyai peranan yang sangat besar dalam mengatur pola interaksi dalam masyarakat Jawa. Prinsip ini menunjuk pada sikap hormat terhadap orang lain dalam wujud bahasa maupun tindakannya.

Berdasarkan dua prinsip utama yang merupakan kaidah dasar dalam kehidupan masyarakat Jawa maka dalam diri orang Jawa tersimpan nilainilai budaya yang memacu pada kehidupan yang rukun dan bersikap hormat terhadap sesama. Nilai-nilai budaya Jawa tersebut antara lain; Prinsip kerukunan: nilai rukun, gotong royong, musyawarah, kebersamaan, tenggang rasa, mawas diri; Prinsip 
hormat: nilai hormat terhadap sesame dalam wujud bahasa dan tindakannya.

\section{1) Prinsip Kerukunan}

\section{a) Nilai Rukun}

Implementasi nilai rukun dalam pelaksanaan Pendidikan Budi Pekerti dilakukan melalui beberapa strategi pembelajaran, diantaranya dengan strategi pembelajaran melalui diskusi, simulasi, bermain bersama,

\section{b) Nilai Gotong Royong}

Implementasi nilai gotong royong dalam pelaksanaan Pendidikan Budi Pekerti dilakukan melalui beberapa starategi pembelajaran, diantaranya dengan strategi pembelajaran bermain, kerja bakti.

\section{c) Nilai Musyawarah}

Implementasi nilai musyawarah dalam pelaksanaan Pendidikan Budi Pekerti dilakukan melalui beberapa strategi pembelajaran diantaranya dengan strategi pembelajaran melalui diskusi, bermain bersama,

\section{d) Nilai Kebersamaan}

Implementasi nilai kebersamaan dalam pelaksanaan Pendidikan Budi Pekerti dilakukan melalui beberapa strategi pembelajaran, diantaranya dengan strategi pembelajaran bermain, metode observasi dan diskusi kelompok.

\section{e) Nilai Tenggang Rasa}

Implementasi nilai tenggang rasa dalam pelaksanaan Pendidikan Budi Pekerti dilakukan melalui beberapa strategi pembelajaran, diantaranya dengan strategi pembelajaran melalui observasi (pengamatan), diskusi, dan outbond.

\section{f) Nilai Mawas Diri}

Implementasi nilai mawas diri dalam pelaksanaan Pendidikan Budi Pekerti dilakukan melalui beberapa strategi pembelajaran, diantaranya dengan strategi pembelajaran melalui penayangan film "peristiwa kerusuhan Mei 1998" dan studi wisata,

\section{2) Prinsip Hormat}

\section{a) Nilai Hormat Dalam Berbicara}

Implementasi nilai hormat dalam berbicara dalam pelaksanaan Pendidikan Budi Pekerti dilakukan melalui strategi pembelajaran dengan diskusi, bermain peran, observasi, pembiasaan, dan keteladanan.

\section{b) Nilai Hormat Dalam Tindakan}

Implementasi nilai hormat dalam tindakan dalam pelaksanaan Pendidikan Budi Pekerti dilakukan melalui kegiatan pembiasaan dan keteladanan.

1) Sebelum dimulai pembelajaran Budi Pekerti guru memeriksa semua siswanya; apakah sudah berpakaian seragam dengan rapi, baju 


$$
\begin{array}{lrr}
\begin{array}{l}
\text { dimasukkan } \\
\text { serta }
\end{array} & \text { memeriksa } \\
\text { termasuk } & \text { kerapian } & \text { dalam } \\
\text { penampilan fisik seperti } & \text { rambut, } \\
\text { apakah siswa ada } & \text { yang } \\
\text { berpenampilan tidak sopan atau } & \\
\text { berlebihan } & \\
\text { 2) Sebelum dan sesudah pelajaran } \\
\text { siswa harus berjabat tangan dan } \\
\text { mencium tangan guru } \\
\text { 3) Pada permulaan dan akhir proses } \\
\text { belajar mengajar selalu dimulai } \\
\text { dengan salam dari guru dan harus } \\
\text { dijawab oleh siswa. }
\end{array}
$$

\section{b. Implementasi Pendidikan Budi Pekerti di Lingkungan Sekolah}

Setiap pagi dan siang hari, pada saat siswa hendak masuk sekolah dan pulang sekolah, siswa-siswa bersalaman dan mencium tangan guru (guru piket) yang telah berdiri di pintu gerbang sekolah. Begitu pula ketika hendak memasuki kelas, maka para siswa berbaris dengan tertib dan teratur, kemudian masuk ke ruang kelas dengan bersalaman, dan mencium tangan guru sambil memberi salam.

Pada setiap hari Jumat, komunikasi di lingkungan sekolah menggunakan bahasa Jawa, baik itu digunakan sebagai bahasa pengantar dalam proses belajar mengajar (PBM), maupun dalam komunikasi siswa dengan siswa, siswa dengan guru/staf karyawan, guru dengan guru/staf karyawan, kepala sekolah. Dalam komunikasi siswa dengan siswa, digunakan bahasa Jawa Ngoko, sedangkan komunikasi dengan guru, staf karyawan, kepala sekolah menggunakan bahasa Jawa Krama. Selain itu, setiap murid yang berpapasan dengan guru diharuskan menyapa dan bersikap agak menundukkan badan sebagai tanda hormat terhadap guru sekaligus dengan orang yang lebih tua. Semua perilaku ini, dimaksudkan untuk menanamkan nilai rukun dan hormat terhadap sesame dalam wujud bahasa dan tindakannya.

Pada setiap hari Senin, diselenggarakan upacara bendera, dengan petugas upacara secara bergiliran untuk tiap kelas. Kelas yang akan mendapat giliran menjadi petugas upacara, biasanya bermusyawarah di kelasnya dengan dipimpin oleh ketua kelas, untuk menentukan siapa-siapa yang akan menjadi petugas upacara. Setelah terbentuk petugas, biasanya pada hari Sabtu sepulang sekolah, satu kelas tersebut berlatih dulu dibawah bimbingan seorang guru pembimbing. Siswa-siswa yang tidak menjadi petugas upacara bertindak sebagai peserta upacara.Setelah latihan pertama, maka ketua kelas meminta masukan dari guru 
pembimbing dan teman-teman yang lain tentang kekurangan dari kekurangan dari latihan tersebut, untuk kemudian diperbaiki. Pada hari Senin, saat pelaksanaan upacara, keberhasilan melaksanakan tugas menjadi tanggung jawab satu kelas, bukan hanya kepada petugas upacara. Semua kegiatan ini dimaksudkan untuk menanamkan nilainilai kebersamaan, musyawarah, dan mawas diri

Dalam momen-momen tertentu, seperti setelah selesai ujian mid semester dan semester, memperingati proklamasi kemerdekaan RI atau HUT Yayasan dari SMP (sekolah swasta), biasanya diadakan pertandingan olahraga, lomba kebersihan antar kelas, atau kegiatan kerja bakti. Dalam kegiatan ini, siswa mendapat pengarahan dari guru agar mereka berlomba sebaik-baiknya, bersikap sportif, tidak saling ejek dan cemooh ketika pertndingan berlangsung, dan berjiwa besar dengan memberi selamat kepada yang menang dan mengakui / menerima kekalahan. Kegiatan ini dimaksudkan untuk menanamkan nilai rukun, gotong royong, kebersamaan, tenggang rasa, dan mawas diri.

Pada saat ada siswa yang sedang berduka,baik karena dia sendiri yang sakit atau orang tua, saudaranya yang sakit, tertimpa musibah atau meninggal dunia maka para siswa dari semua kelas dimintai / secara spontan memberikan semacam tali asih baik berupa barang maupun uang untuk diberikan kepada siswa atau keluarganya yang sedang berduka tersebut. Biasanya para siswa dalam satu kelas dengan didampingi wali kelas dari siswa yang berduka akan membesuk/ melayat ke tempat yang bersangkutan. Sedangkan dari kelas lain, biasanya melalui perwakilan. Hal ini juga berlaku bagi para guru, staf karyawan dan kepala sekolah yang sedang ditimpa musibah. Kegiatan ini merupakan keteladanan dan pembiasaan bagi siswa tentang arti pentingnya nilai-nilai kebersamaan, tenggang rasa, rukun, dan nilai gotong royong.

Pada setiap hari Jumat, khususnya di SMP swasta yang berbasis Islam maupun di beberapa SMP Negeri mengadakan sholat Jumat di sekolah. Petugas Jumatan secara bergiliran untuk tiap kelas. Selain itu, dalam momen-momen hari besar agama juga diadakan sholat Idul Fitri, Idul Adha serta pengajian bersama

Pada saat Hari Raya Idul Adha pihak sekolah biasanya mengadakan penyembelihan hewan kurban dengan melibatkan semua warga sekolah. Hewan kurban berasal dari iuran warga sekolah termasuk siswa. Sedangkan 
untuk SMP swasta berbasis Kristen dan Katholik serta SMP Negeri juga mengadakan sembahyang pada hari minggu di sekolah atau mengadakan peringatan Hari Natal, Kenaikan Isa Almasih di sekolah. Kegiatan -kegiatan tersebut di atas, dimaksudkan untuk memberikan keteladanan dan pembiasaan bagi siswa tentang arti pentingnya nilai rukun, kebersamaan, tenggang rasa, dan nilai hormat.

\section{c. Kualitas Pendidikan Budi Pekerti}

\section{Dalam Perspektif Pendidikan}

\section{Multikultural}

Kebijakan kurikulum

pendidikan budi pekerti merupakan sebuah kebijakan pendidikan yang berbasis mulltikultural yang menghargai adanya perbedaan. Hal ini mengingat bahwa kerusuhan yang terjadi di Solo telah melibatkan rasa sentiment terhadap etnik tertentu yaitu etnik Cina. Oleh karena itu, materi pendidikan budi pekerti merupakan cerminan dari nilai-nilai budaya Jawa. Pemilihan materi ini cukup beralasan karena nilai-nilai budaya Jawa mendasarkan kepada dua prinsip utama yaitu prinsip rukun dan prinsip hormat yang bertujuan untuk mempertahankan masyarakat dalam keadaan yang harmonis yaitu dalam keadaan selaras, tenang, dan tenteram tanpa perselisihan atau pertentangan

(konflik).
Berdasarkan dua prinsip utama yang merupakan kaidah dasar dalam kehidupan masyarakat Jawa maka dalam diri orang Jawa tersimpan nilainilai budaya yang memacu pada kehidupan yang rukun dan bersikap hormat terhadap sesama. Nilai-nilai budaya Jawa tersebut antara lain; Prinsip kerukunan: nilai rukun, gotong royong, musyawarah, kebersamaan, tenggang rasa (toleransi), mawas diri; Prinsip hormat: nilai hormat terhadap sesame dalam wujud bahasa dan tindakannya. Nilai-nilai budaya tersebut sangat sesuai dengan konsep pendidikan multikultural yang menghargai adanya perbedaan dan lenbih mengutamakan rasa kebersamaan.

$$
\text { Ciri-siri dari pendidikan }
$$
multikultural diantaranya: 1). Tujuannya membentuk manusia dan masyarakat yang berbudaya, 2). Materinya mengajarkan nilai-nilai luhur kemanusiaan, nilai-nilai bangsa dan nilai-nilai kelompok etnis (cultural), 3). Metodenya demokratis, yang menghargai adanya perbedaan dan keberagaman budaya bangsa dan kelompok etnis (cultural), 4). Evaluasinya ditentukan pada penilaian terhadap tingkah laku anak didik yang meliputi persepsi, apresiasi, dan tindakan terhadap budaya lainnya 
(Choirul Mahfud, 2006: 179). Tujuan pendidikan budi pekerti, salah satunya adalah terbentuknya perilaku siswa yang mencerminkan nilai-nilai budaya Jawa yang mengutamakan keadaan yang harmonis yaitu keadaan yang selaras, tenang, tenteram, tanpa perselisihan atau pertentangan. (manusia berbudaya).

Dilihat materinya, pendidikan budi pekerti mengajarkan nilai-nilai kemanusiaan, dimana nilai-nilai budaya Jawa termasuk di dalamnya, seperti nilai rukun, tenggang rasa, kebersamaan, gorong royong, musyawarah, mawas diri, toleransi, saling menghormati, yang kesemuanya akan menghapuskan atau mengurangi prasangka atau prejudice terhadap kelompok lain. Dilihat dari metodenya, maka pendidikan budi pekerti dilaksanakan secara demokratis yang menghargai adanya perbedaan dan mengutamakan kebersamaan, persatuan, dan saling membutuhhkan yang dilihat dari strategi pembelajarannya seperti, simulasi, permainan, diskusi, outbond, pembiasaan, keteladanan yang menanamkan rasa tanggung jawab, kerjasama, toleransi, tenggang rasa, musyawarah, gotong royong dan lain sebagainya. Dari segi evaluasinya, maka penilaian terhadap pelaksanaan pendidikan budi pekerti lebih difokuskan pada sikap dan perilku siswa dalam interaksi sosial di sekolahnya yang tidak bertentangan dengan nilainilai budaya Jawa yang mendukung pelaksanaan pendidikan multikultural dari aspek materinya.

\section{B. Pembahasan Hasil Penelitian}

Kebijakan kurikulum pendidikan budi pekerti merupakan sebuah kebijakan pendidikan yang berbasis mulltikultural yang menghargai adanya perbedaan. Hal ini mengingat bahwa kerusuhan yang terjadi di Solo telah melibatkan rasa sentiment terhadap etnik tertentu yaitu etnik Cina. Oleh karena itu, materi pendidikan budi pekerti merupakan cerminan dari nilai-nilai budaya Jawa. Pemilihan materi ini cukup beralasan karena nilai-nilai budaya Jawa mendasarkan kepada dua prinsip utama yaitu prinsip rukun dan prinsip hormat yang bertujuan untuk mempertahankan masyarakat dalam keadaan yang harmonis yaitu dalam keadaan selaras, tenang, dan tenteram tanpa perselisihan atau pertentangan (konflik). Berdasarkan dua prinsip utama yang merupakan kaidah dasar dalam kehidupan masyarakat Jawa maka dalam diri orang Jawa tersimpan nilai- 
nilai budaya yang memacu pada kehidupan yang rukun dan bersikap hormat terhadap sesama. Nilai-nilai budaya Jawa tersebut antara lain; Prinsip kerukunan: nilai rukun, gotong royong, musyawarah, kebersamaan, tenggang rasa (toleransi), mawas diri; Prinsip hormat: nilai hormat terhadap sesame dalam wujud bahasa dan tindakannya. Nilai-nilai budaya tersebut sangat sesuai dengan konsep pendidikan multikultural yang menghargai adanya perbedaan dan lenbih mengutamakan rasa kebersamaan.

Ciri-siri dari pendidikan multikultural diantaranya: 1). Tujuannya membentuk manusia dan masyarakat yang berbudaya, 2). Materinya mengajarkan nilai-nilai luhur kemanusiaan, nilai-nilai bangsa dan nilai-nilai kelompok etnis (cultural), 3). Metodenya demokratis, yang menghargai adanya perbedaan dan keberagaman budaya bangsa dan kelompok etnis (cultural), 4). Evaluasinya ditentukan pada penilaian terhadap tingkah laku anak didik yang meliputi persepsi, apresiasi, dan tindakan terhadap budaya lainnya (Choirul Mahfud, 2006: 179). Tujuan pendidikan budi pekerti, salah satunya adalah terbentuknya perilaku siswa yang mencerminkan nilai-nilai budaya
Jawa yang mengutamakan keadaan yang harmonis yaitu keadaan yang selaras, tenang, tenteram, tanpa perselisihan atau pertentangan. (manusia berbudaya). Di lihat materinya, pendidikan budi pekerti mengajarkan nilai-nilai kemanusiaan, dimana nilainilai budaya Jawa termasuk di dalamnya, seperti nilai rukun, tenggang rasa, kebersamaan, gorong royong, musyawarah, mawas diri, toleransi, saling menghormati, yang kesemuanya akan menghapuskan atau mengurangi prasangka atau prejudice terhadap kelompok lain. Dilihat dari metodenya, maka pendidikan budi pekerti dilaksanakan secara demokratis yang menghargai adanya perbedaan dan mengutamakan kebersamaan, persatuan, dan saling membutuhhkan yang dilihat dari strategi pembelajarannya seperti, simulasi, permainan, diskusi, outbond, pembiasaan, keteladanan yang menanamkan rasa tanggung jawab, kerjasama, toleransi, tenggang rasa, musyawarah, gotong royong dan lain sebagainya. Dari segi evaluasinya, maka penilaian terhadap pelaksanaan pendidikan budi pekerti lebih difokuskan pada sikap dan perilku siswa dalam interaksi sosial di sekolahnya yang tidak bertentangan dengan nilainilai budaya Jawa yang mendukung 
pelaksanaan pendidikan multikultural dari aspek materinya.

Pendidikan multikultural sebaiknya ditekankan pada mata pelajaran kebangsaan dan moral. Pendidikan budi pekerti yang diorientasikan dalam perspektif multikultural sudah tepat untuk mengatasi permasalahan yang ada.

Ada dua hal yang harus diperhatikan untuk mewujudkan pendidikan multikultural yang mampu memberikan ruang kebebasan bagi semua kelompok yang berbeda untuk berekspresi. Pertama adalah dialog. Dialog meniscayakan adanya persamaan dan kesamaan di antara pihak-pihak yang terlibat. Dengan dialog, diharapkan terjadi sumbang pemikiran yang pada gilirannya akan memperkaya kebudayaan atau peradaaban yang bersangkutan. Dialog sangat penting untuk mencari titik temu antar peradaban dan kebudayaan yang ada. Dialog diharapkan dapat mencari titiktitik persamaan sambil memahami titiktitik perbedaan antar kebudayaan Kedua adalah toleransi. Toleransi adalah sikap menerima bahwa orang lain berbeda dengan kita.Dialog dan toleransi merupakan satu kesatuan yang tidak dapat dipisahkan (Choirul Mahfud, 2006: xiii). Bila dialog itu bentuknya maka toleransi itu isinya. Dialog dan toleransi merupakan dua aspek yang juga ditekankan dalam proses pendidikan budi pekerti. Hal ini direalisasikan, salah satunya melalui dialog antar siswa dari berbagai multikultur yang ada di SMP kota Surakarta. Walaupun ini merupakan sebuah eksperimen dalam sekelompok kecil siswa, tetapi hal ini akan dapat merupakan embrio dan bahan masukan yang berharga dalam mewujudkan pendidikan multikultur yang menghargai adanya perbedaan dan penuh rasa toleransi. Dalam hal ini, dialog dilakukan antar siswa dari berbagai kelompok etnis, seperti siswasiswa dari keturunan Cina, Arab, India, dan pribumi sendiri, dari berbagai agama, dari sekolah-sekolah negeri, swasta, dari yayasan Islam, Kristen, Katolik, atau Nasionalis. Dialog dikemas dalam sebuah diskusi atau permainan, presentasi, dalam situasi yang santai dan penuh kebersamaan.

Ada tiga urgensi pendidikan multikultural, yaitu 1). Pendidikan multikultural berfungsi sebagai sarana alternatif pemecahan masalah, 2). Supaya siswa tidak tercerabut dari akar budayanya, 3). Sebagai landasan pengembangan kurikulum nasional (Choirul Mahfud, 2006: 207-214). Kurikulum pendidikan budi pekerti merupakan sebuah kebijakan daerah 
yang diadakan sebagai salah satu upaya preventif dalam mencegah terjadinya budaya kekerasan di kota Surakarta. Untuk itu, materi pendidikan budi pekerti dipilih dan merupakan pencerminan nilai-nilai budaya Jawa yang dianggap sesuai dengan tujuan dan fungsi diadakannya pendidikan budi pekerti tersebut. Harapannya agar nilainilai budaya Jawa membudaya dalam sikap, bicara, dan perilaku siswa sehingga akan tercipata sebuah kehidupan yang menghargai adanya perbedaan, dalam suasana yang harmonis, tenang, tenteram tanpa perselisihan atau pertentangan. Kurikulum pendidikan budi pekerti dengan materi dan strategi pembelajarannya, dapat dijadikan sebagai bahan refleksi, masukan atau landasan dalam pengembangan kurikulum nasional.

\section{Simpulan dan Saran}

\section{A. Simpulan}

1. Para guru pendidikan budi pekerti telah menerapkan pembelajaran budi pekerti berbasis multikultural melalui metode diskusi, simulasi, permainan, kerja bakti, observasi, maupun pemberian materi budi pekertif di kelas. Namun demikian, sebagian besar guru belum memahami konsep pendidikan multikultural.

2. Para guru dan stakcholders sangat mendukung adanya rencana pembelajaran budi pekerti berbasis multikultural, mengingat kasus kekerasan yang berbau sara yang sering melibatkan para pelajar.

3. Pembelajaran budi pekerti telah dilaksanakan dengan berbasis multikultural melalui proses pembelajaran, pembiasaan, dan keteladanan. Pembiasaan dan keteladanan dilakukan oleh semua warga sekolah, sedangkan proses pembelajaran dilaksanakan oleh pengampu pendidikan budi pekerti.

\section{B. Saran}

1. Perlu adanya sosialisasi tentang konsep pendidikan multikultural bagi guru-guru pengampu pendidikan budi pekerti di SMP Kota Surakarta. Hal ini dikarenakan sebagian besar guru pengampu pendidikan budi pekerti belum memahami tentang konsep pendidikan multikultural.

2. Perlu adanya komitmen dari Pemerintah Kota Surakarta/Dinas Dikpora Kota Surakarta untuk tetap mendukung pendidikan budi pekerti 
melalui sebuah kebijakan yang tepat demi keberlangsungan pendidikan budi pekerti seperti rencana awal ketika dikeluarkannya kebijakan penerapan kurikulum pendidikan budi pekerti di SMP Kota Surakarta sebagai upaya mengatasi budaya kekerasan di kalangan pelajar.

3. Perlu adanya kesamaan visi dan misi dari semua warga sekolah untuk komitmen mendukung pendidikan budi pekerti di sekolah.

4. Perlu adanya relasi sosial yang baik antara warga sekolah dengan warga lingkungan sekitar sekolah untuk menciptakan lingkungan yang kondusif bagi keberhasilan pendidikan budi pekerti.

\section{Daftar Pustaka}

Banks,James. 2000. Multicultural Education: Transforming the Mainstream curriculum. Connecticut: Dushkin?McGrawHill, A Division of The McGrawHill Companies.

Abd.Rahman. (2004). Pendidikan Tanpa Kekerasan: Tipelogi kondisi, Kasus dan Konsep. Yogyakarta: Tiara Wacana Yogya.

Choirul Mahfud. (2006). Pendidikan Multikultural. Yogyakarta: Pustaka Pelajar.
Conny Semiawan dkk. (2003). Tata Krama Pergaulan. Jakarta: Balai Pustaka.

Edi Sedyawati dkk. (1999). Pedoman Penanaman Budi Pekerti Luhur. Jakarta: Balai Pustaka.

Franz Magnis Suseno. (1999). Etika Jawa: Sebuah Analisa Falsafi tentang Kebijaksanaan Hidup

G. Surya Alam.. (1981). Etika dan Etiket Bergaul. Semarang: Penerbit Aneka Ilmu.

Imam Khomeini. (2004). Memupuk Keluhuran Budi Pekerti. Jakarta: Penerbit Misbah

Kodiran. (1988). Kebudayaan Jawa. Dalam Koentjaraningrat (Ed.). Manusia dan Kebudayaan. Jakarta: PT Djambatan, 1998.

M.Furqon Hidatatullah. (2007). Mengantar Calon Pendidik Berkarakter di Masa Depan. Surakarta: Sebelas Maret University Press.

Mulder, Niels. (1996). Kepribadian Jawa dan Pembangunan Nasional. Yogyakarta: Gadjah Mada University Press.

Muthohar, M. Aries Muthohar. (2001). Tata Krama di Rumah, Sekolah, dan Masyarakat. Surabaya: Penerbit SIC.

Nurul Zuriah. (2007). Pendidikan Moral \& Budi Pekerti Dalam Perspektif Perubahan. Jakarta: Bumi Aksara.

Noeng Muhadjir. (2011). Metodologi Penelitian. Yogyakarta: Rake Sarasin 
Pelu, Musa. (2001). Integrasi Nasional Ditinjau Dari Sikap Terhadap Nilai-Nilai Budaya Jawa Dan Pemahaman Sejarah Nasional Indonesia. Tesis, magister, tidak diterbitkan, Universitas Negeri Jakarta, Jakarta.

Pemerintah Kota Surakarta. (2004). Pendidikan Budi Pekerti Pada SMP di Kota Surakarta. Surakarta: Kota Surakarta.

Pratt, Harold. ( Agustus, 2006). Evaluation Research in Education,Artikel. Diambil pada tanggal 20 Agustus 2006, dari http://www.edu.plymouth.ac.uk /resined/evaluation/ index.htm.

Sabar Narimo. (2009). Karakteristik Psiko-Sosio Kultural Manusia Dalam Serat Wulang-Reh Karya Pakoe Boewono IV (Tinjauan Pendidikan Informal Masyarakat Jawa). Disertasi doktor, tidak diterbitkan, Universitas Negeri Yogyakarta, Yogyakarta.

Spadley, James. (1979). Teh Ethnographic Interview. New York: Holt, Rinechart and Wiston

Sri Agus. (2000). Sikap dan Perilaku Masyarakat Surakarta Pasca Kerusuhan Mei 1989. Surakarta: Fakultas Sastra Universitas Sebelas Maret.

Thomas Wijaya Bratawijaya. (1997). Masyarakat dan Mengenal Budaya Jawa. Yogyakrta: PT Praditya Paramita.

Yayah kisbiyah dkk. (2000). Melawan Kekerasan Tanpa Kekerasan. Yogyakarta: Pustaka Pelajar. 